\title{
Pengaruh Model Pembelajaran Think-Pair-Share terhadap Hasil Belajar Siswa Kelas V (Lima) Materi Organ Tubuh Manusia dan Hewan
}

\author{
Joko Sulianto ${ }^{1^{*}}$, Veryliana Purnamasari² ${ }^{2}$ Bayu Febriarianto ${ }^{3}$ \\ ${ }^{123}$ Fakultas Ilmu Pendidikan, Universitas PGRI Semarang, Indonesia
}

\section{A R T I C LE I N F O Article history: Received 18 February 2019 Received in revised form 20 March 2019 Accepted 20 April 2019 Available online 20 May 2019 \\ Kata Kunci: Model Think-Pair-Share, Hasil Belajar \\ Keywords: Think-Pair-Share Model, Learning Outcomes}

\begin{abstract}
A B S T R A K
Jenis penelitian ini adalah eksperimen dalam bentuk True Experimental Design dengan desain Pretest-Postest Control Design. Populasi dalam penelitian ini berjumlah 23 siswa kelas $\mathrm{V}$ (lima) dengan menggunakan teknik nonprobability sampling yaitu sampel jenuh. Analisis instrumen yang digunakan adalah validitas, reliabilitas, dan daya pembeda. Data dalam penelitian ini diperoleh melalui teknik tes, dokumentasi dan observasi. Hasil analisis data dengan uji t satu pihak yaitu diperoleh thitung $=4,7312$. Dari daftar distribusi t dengan $\mathrm{dk}=12$ $+11-2=21$ dan taraf nyata $5 \%$ diperoleh ttabel $=1,72$. Karena thitung $>$ ttabel maka HO ditolak. Ketuntasan belajar individu dan klasikal kelompok eksperimen yang menggunakan model Think-pair-Share lebih tinggi dari pada kelompok kontrol. Hal ini ditunjukkan dengan nilai tes akhir kelas eksperimen mencapai 90,91\% dari jumlah siswa yang mendapat nilai di atas KKM (70) dengan nilai rata-rata kelas sebesar 77,82 . Sedangkan nilai tes akhir kelas kontrol mencapai $75 \%$ dari jumlah siswa yang mendapat nilai di atas KKM (70) dengan nilai ratarata kelas sebesar 70,33. Kesimpulannya bahwa model Think-pairShare ada pengaruh yang signifikan terhadap hasil belajar siswa kelas V (lima) SDN Sumbermulyo Kecamatan Bulu. Berdasarkan hasil penelitian ini saran yang disampaikan adalah model pembelajaran Think-pair-Share dapat digunakan sebagai salah satu alternatif guru dalam mengajar.
\end{abstract}

The type of this research is experimental in the form of True Experimental Design with Pretest-Postest Design. The population of this research is 23 students of fifth grade by using a nonprobability sampling technique, which is a saturated sample. The instrumental analysis used is validity, reliability, and distinguishing power. The data is obtained through the technique of test, documentation, and observation. The result of the data analysis with one-tailed $t$ and it is obtained tcount $=4,7312$. From t distribution data with $\mathrm{dk}=12+11-2=21$ and the real rate $5 \%$ can be obtained ttable $=1,72$. Because tcount $>$ ttable, so $\mathrm{HO}$ is rejected. The learning completeness in an individual and classical group can be obtained by carrying out an experiment by using the Think-pairShare model. The result is higher than the control group. It is indicated by the experiment of the final grade test score, which is $90.91 \%$. This percentage is from the total students who get the score above $\mathrm{KKM}(70)$ with the class mean score is 77.82 . Whereas, the control of final grade test score reaches $75 \%$ from the total number of students who get the score above KKM (70) with the class mean score is 70.33. The conclusion is there is a significant effect of the Think-pair-Share model towards the learning outcomes of fifth-grade students of SDN Sumbermulyo, Bulu sub-district. The suggestion based on this research result is the learning model named Think-pair-Share can be used as an alternative for teachers in teaching.

\footnotetext{
1 Corresponding author.

E-mail addresses: jokosulianto@upgris.ac.id (Joko Sulianto)
} 


\section{Pendahuluan}

Pasal 1 UU SISDIKNAS no. 20 tahun 2003 disebutkan bahwa Sistem Pendidikan Nasional adalah keseluruhan komponen pendidikan yang saling terkait secara terpadu untuk mencapai tujuan pendidikan nasional. Berangkat dari bunyi pasal ini dapat diketahui bahwa pendidikan adalah sistem yang merupakan suatu totalitas struktur yang terdiri dari komponen yang saling terkait dan secara bersama menuju kepada tercapainya tujuan (Soetarno, 2003: 2). Adapun komponen-komponen dalam pendidikan nasional antara lain adalah lingkungan, sarana-prasarana, sumberdaya, dan masyarakat. Komponen-komponen tersebut bekerja secara bersama-sama, saling terkait dan mendukung dalam mencapai tujuan pendidikan (Munirah, 2015).

Pendidikan lebih dari sekedar pengajaran, yang dapat dikatakan sebagai suatu proses transfer ilmu, transformasi nilai, dan pembentukan kepribadian dengan segala aspek yang dicakupnya. Dengan demikian pengajaran lebih berorientasi pada pembentukan spesialis atau bidangbidang tertentu, oleh karena itu perhatian dan minatnya lebih bersifat teknis. Pendidikan merupakan suatu proses yang diperlukan untuk mendapatkan keseimbangan dan kesempurnaan dalam perkembangan individu maupun masyarakat. Penekanan pendidikan dibanding dengan pengajaran terletak pada pembentukan kesadaran dan kepribadian individu atau masyarakat di samping transfer ilmu dan keahlian. Dengan proses semacam ini suatu bangsa atau negara dapat mewariskan nilai-nilai keagamaan, kebudayaan, pemikiran dan keahlian kepada generasi berikutnya, sehingga mereka betul-betul siap menyongsong masa depan kehidupan bangsa dan negara yang lebih cerah. Pendidikan juga merupakan sebuah aktifitas yang memiliki maksud atau tujuan tertentu yang diarahkan untuk mengembangkan potensi yang dimiliki manusia baik sebagai manusia ataupun sebagai masyarakat dengan sepenuhnya (Nurkholis, 2013).

Pembelajaran dapat dikatakan sebagai hasil dari memori, kognisi, dan metakognisi yang berpengaruh terhadap pemahaman. Sedang Wenger mengatakan, "Pembelajaran bukanlah aktivitas, sesuatu yang dilakukan oleh seseorang ketika ia tidak melakukan aktivitas yang lain. Pengertian pembelajaran yang disampaikan pada intinya sama meski penyampaiannya berbeda, bahwa pembelajaran merupakan hasil dari kognisi yang berpengaruh terhadap pemahaman yang diperoleh tidak melalui aktivitas lain. Dengan demikian, pembelajaran dapat diartikan sebagai proses modifikasi dalam kapasitas manusia yang bisa dipertahankan dan ditingkatkan levelnya.

Belajar adalah merupakan suatu proses, suatu kegiatan dan bukan suatu hasil atau tujuan. Belajar bukan hanya mengingat, akan tetapi lebih luas daripada itu, yakni mengalami. Hasil belajar bukan suatu penguasaan hasil latihan melainkan perubahan kelakuan" (Hamalik, 2005: 37). Belajar ialah suatu proses usaha yang dilakukan seseorang untuk memperoleh suatu perubahan tingkah laku yang baru secara keseluruhan, sebagai hasil pengalamanya sendiri dalam interaksi dengan lingkunganya" (Slameto, 2003:2). Dampak pengajaran adalah hasil yang dapat diukur dengan segera atau secara langsung. Sedangkan dampak pengiring adalah hasil belajar siswa yang tampak secara tidak langsung atau merupakan transfer hasil belajar" (Dimyati dan Mudjiono, 2006:295). (Sutrisno, 2016) Mengungkapkan hasil belajar merupakan sebuah tindakan evaluasi yang dapat mengungkap aspek proses berpikir (cognitive domain) juga dapat mengungkap aspek kejiwaan lainnya, yaitu aspek nilai atau sikap (affective domain) dan aspek keterampilan (psychomotor domain) yang melekat pada diri setiap individu peserta didik. Ini artinya melalui hasil belajar dapat terungkap secara holistik penggambaran pencapaian siswa setelah melalui pembelajaran. hasil belajar adalah sesuatu yang dicapai atau diperoleh siswa berkat adanya usaha atau pikiran yang mana hal tersebut dinyatakan dalam bentuk penguasaan, pengetahuan dan kecakapan dasar yang terdapat dalam berbagai aspek kehidupan sehingga nampak pada diri indivdu penggunaan penilaian terhadap sikap, pengetahuan dan kecakapan dasar yang terdapat dalam berbagai aspek kehidupan sehingga nampak pada diri individu perubahan tingkah laku secara kuantitatif (Setiawan Hendri, 2014). Hasil belajar siswa menurut Winkel adalah keberhasilan yang dicapai oleh siswa, yakni prestasi belajar siswa di sekolah yang mewujudkan dalam bentuk angka. Sedangkan menurut Winarno hasil belajar siswa bagi kebanyakan orang berarti ulangan, ujian atau tes. Maksud ulangan tersebut ialah untuk memperoleh suatu indek dalam menentukan keberhasilan siswa.

Indikator utama hasil belajar siswa adalah sebagai berikut: (a) Ketercapaian Daya Serap terhadap bahan pembelajaran yang diajarkan, baik secara individual maupun kelompok. Pengukuran ketercapaian daya serap ini biasanya dilakukan dengan penetapan Kriteria Ketuntasan Belajar Minimal (KKM); (b) Perilaku yang digariskan dalam tujuan pembelajaran telah dicapai oleh siswa, baik secara individual maupun kelompok. Namun demikian, menurut Syaiful Bahri Djamarah dan Aswan Zain, indikator yang banyak dipakai sebagai tolak ukur keberhasilan adalah daya serap.

Sedangkan model pembelajaran menurut Kardi dan Nur ada lima model pembelajaran yang dapat digunakan dalam mengelola pembelajaran, yaitu: pembelajaran langsung; pembelajaran kooperatif; pembelajaran berdasarkan masalah; diskusi; dan learning strategi. Dedi Supriawan dan A. Benyamin 
Surasega mengetengahkan 4 (empat) kelompok model pembelajaran, yaitu: (1) model interaksi sosial; (2) model pengolahan informasi; (3) model personal-humanistik; dan (4) model modifikasi tingkah laku. Kendati demikian, seringkali penggunaan istilah model pembelajaran tersebut diidentikkan dengan strategi pembelajaran.

Think-pair-share merupakan salah satu tipe pembelajaran kooperatif yang dikembangkan oleh Frank Lyman, dkk dari Universitas Maryland pada tahun 1985 sebagai salah satu struktur kegiatan cooperative learning. Think-pair-share memberikan waktu kepada para siswa untuk berpikir dan merespon serta saling bantu satu sama lain. Think-pair-share memberi siswa kesempatan untuk bekerja sendiri serta bekerja sama dengan orang lain. Keunggulan lain dari pembelajaran ini adalah optimalisasi partisipasi siswa.

Kagan dalam Widarti menyatakan manfaat think-pair-share: (1) Para siswa menggunakan waktu yang lebih banyak untuk mengerjakan tugasnya dan untuk mendengarkan satu sama lain, ketika mereka terlibat dalam kegiatan Think-pair-share lebih banyak siswa yang mengangkat tangan mereka untuk menjawab setelah berlatih dalam pasangannya. Para siswa mungkin mengingat secara lebih seiring penambahan waktu tunggu dan kualitas jawaban mungkin menjadi lebih baik. (2) Para guru juga mempunyai waktu yang lebih banyak untuk berpikir ketika menggunakan Think-Pair-Share. Mereka dapat berkonsentrasi mendengarkan jawaban siswa, mengamati reaksi siswa, dan mengajukan pertanyaan tingkat tinggi. Fogarty dan Robin menyatakan bahwa teknik belajar mengajar think-pair-share mempunyai beberapa keuntungan: (1) Mudah dilaksanakan dalam kelas yang besar; (2) Memberikan waktu kepada siswa untuk merefleksikan isi materi pelajaran; (3) Memberikan waktu kepada siswa untuk melatih mengeluarkan pendapat sebelum berbagi dengan kelompok kecil atau kelas secara keseluruhan. Dengan teknik belajar mengajar think-pair-share yang disebutkan Fogarty dan Robin siswa dilatih untuk banyak berfikir dan saling tukar pendapat baik dengan teman sebangku ataupun dengan teman sekelas, sehingga dapat meningkatkan hasil belajar ranah kognitif siswa karena siswa dituntut untuk mengikuti proses pembelajaran agar dapat menjawab setiap pertanyaan dan berdiskusi.

Masalah belajar adalah masalah bagi setiap manusia, dengan belajar manusia memperoleh keterampilan, kemampuan sehingga terbentuklah sikap dan bertambahlah ilmu pengetahuan. Jadi hasil belajar itu adalah suatu hasil nyata yang dicapai oleh siswa dalam usaha menguasai kecakapan jasmani dan rohani di sekolah yang diwujudkan dalam bentuk raport pada setiap semester. Untuk mengetahui perkembangan sampai di mana hasil yang telah dicapai oleh seseorang dalam belajar, maka harus dilakukan evaluasi. Untuk menentukan kemajuan yang dicapai maka harus ada kriteria (patokan) yang mengacu pada tujuan yang telah ditentukan sehingga dapat diketahui seberapa besar pengaruh strategi belajar mengajar terhadap keberhasilan belajar siswa.

Belajar memerlukan aktivitas, seperti yang dikemukakan oleh Hamalik (2001) "pengajaran yang efektif adalah pengajaran yang menyediakan kesempatan belajar sendiri atau melakukan aktivitas sendiri". Senada dengan hal tersebut, Winkel (dalam Riyanto, 2009) mengatakan "belajar adalah suatu aktivitas mental/psikis yang berlangsung dalam interaksi aktif dengan lingkungan, yang menghasilkan perubahan-perubahan dalam pengetahuanpemahaman, keterampilan, dan nilai sikap". Berdasarkan pendapat para ahli, dapat ditarik kesimpulan bahwa aktivitas belajar adalah segala kegiatan belajar yang saling berinteraksi sehingga menimbulkan perubahan dari perilaku belajarnya, misalnya tidak tahu menjadi tahu, dari tidak mampu melakukan kegiatan jadi mampu melakukan kegiatan, dan lain sebagainya. Aktivitas siswa dalam kegiatan pembelajaran mempunyai peranan yang sangat penting dalam pembelajaran, tanpa aktivitas belajar itu tidak mungkin akan berlangsung dengan baik.

Hasil belajar merupakan sesuatu yang diperoleh siswa setelah mengikuti proses pembelajaran. Menurut Kunandar (2007) "hasil belajar adalah kemampuan siswa dalam memenuhi suatu tahapan pencapaian pengalaman belajar dalam satu kompetensi dasar". Menurut Abdurrahman (2003), "hasil belajar adalah kemampuan yang diperoleh anak setelah melalui kegiatan belajar" (Ayuwanti, 2016)

Penelitian ini dikuatkan oleh penelitian sebelumnya yang dilakukan oleh I Wayan (2015) yang berjudul "Pengaruh Model Pembelajaran Koopertif Tipe Think Pair Share (TPS) Terhadap Hasil Belajar IPA Siswa Kelas VI SD Gugus Letda Made Putra Kecamatan Denpasar Utara Tahun Ajaran 2014/2015" yang menunjukan bahwa nilai rata-rata postes kelas eksperimen setelah diberi perlakuan mendapat 77,48 dan kelas kontrol yang tidak diberi perlakuan mendapat nilai rata-rata sebesar 69,78. Hal ini menunjukan bahwa model pembelajaran Think Pair Share memilik pengaruh dalam meningkatkan hasil belajar. Hal senada juga diungkapkan oleh Prasetyo (2018) yang menyatakan bahwa model pembelajaran Think Pair Share berbantu permainan teka-teki berantai dapat meningkatkan keaktifan, daya fokus dan hasil belajar siswa. Sehingga menghasilkan data yang signifikan dilihat dari hasil postes yang sudah mencapai KKM pada pembelajaran tematik tema 6 "Organ Tubuh Manusia dan Hewan" subtema 3 "Cara Hidup, Manusia, Hewan dan Tumbuhan" di kelas VB SDN Gayamsari 01 Semarang. Lina Surayya (2014) terdapat perbedaan hasil belajar antara siswa yang mengikuti model pembelajaran TPS dengan siswa yang 
mengikuti model pembelajaran konvensional (MPK) $(\mathrm{F}=187,110 ; \mathrm{p}<0,05) ;(2)$ tidak terdapat pengaruh interaksi antara model pembelajaran TPS dan KBK terhadap hasil belajar $(F=3,238 ; p>0,05)$. Berdasarkan hasil penelitian ini dapat direkomendasikan bahwa model pembelajaran TPS dapat digunakan sebagai alternatif model pembelajaran untuk meningkatkan hasil belajar IPA.

Dari hasil observasi pada siswa kelas V (Lima) SDN Sumbermulyo Kecamatan Bulu hasil belajar pada Mata Pelajaran Ilmu Pengetahuan Alam (IPA) tergolong rendah. Hal itu ditunjukkan dalam data bahwa dari 23 siswa hanya 8 siswa (31,82\%) yang memperoleh nilai di atas Kriteria Ketuntasan Minimal (KKM) yaitu 65. Sisanya sebanyak 15 siswa $(68,18 \%)$ nilainya di bawah KKM. Selain data tersebut juga didukung dengan hasil wawancara dengan siswa yang menyebutkan bahwa hampir semua siswa menyatakan kesulitan memahami materi IPA yang diajarkan gurunya.

Peneliti menetapkan alternatif tindakan untuk meningkatkan kualitas pembelajaran yang dapat mendorong siswa aktif dalam pembelajaran IPA dengan penerapan Think-pair-share (TPS). TPS merupakan jenis pembelajaran kooperatif yang dirancang untuk mempengaruhi pola interaksi siswa. Dengan model ini siswa dilatih untuk mengemukakan pendapat dan menghargai pendapat orang lain dengan tetap berpedoman pada materi dan tujuan pembelajaran. Siswa juga dapat terlibat aktif dalam PBM karena model ini dapat dilaksanakan dalam kelompok kecil maupun berpasangan sehingga dapat dilihat kemampuan siswa dalam melakukan kerjasama dalam kelompoknya. Selain itu juga berguna untuk mengembangkan pengetahuan secara mandiri, sikap dan keterampilannya yang pada akhirnya akan berdampak pada aktivitas guru dan hasil belajar siswa.

Dari uraian latar belakang di atas maka judul penelitian yang diusulkan adalah Pengaruh Model Pembelajaran think-pair-share terhadap Hasil Belajar Siswa Kelas V (lima) Materi Organ Tubuh Manusia dan Hewan Semester Gasal 2017/2018 SDN Sumbermulyo Kecamatan Bulu.

\section{Metode}

Penelitian ini menggunakan bentuk desain True Experimental Design dengan jenis Pretest-Posttest Control Group Design. Peneliti menentukan subjek yang akan diteliti terlebih dahulu dan membuat soal yang berdasarkan kisi-kisi. Peneliti selanjutnya mengujicobakan intrumen soal pada kelas yang dipilih. Pengujicobaan intrumen ini berfungsi untuk mengetahui validitas butir soal, realibilitas soal, tingkat kesukaran dan daya beda melalui analisis data. Peneliti memulai melakukan pretest pada kelas ekperiman dan kelas kontrol. Pretest ini bertujuan untuk menganalisa data awal. Peneliti memberikan soal posttest pada kelas ekperiman dan kontrol. Pemberian soal posttest ini berguna untuk mengetahui data hasil posttest yang nantinya data tersebut di analisa dan digunakan untuk menyusun hasil penelitian.

Arikunto berpendapat bahwa populasi adalah "keseluruhan subjek penelitian". Sedangkan Sugiyono berpendapat bahwa"Populasi adalah wilayah generalisasi yang atas objek atau subyek yang mempengaruhi kualitas dan karakteristik tertentu yang ditetapkan oleh peneliti untuk dipelajari dan kemudian ditarik kesimpulannya". Populasi ini penting karena akan menjadi dasar dalam penentuan objek penelitian yang nantinya digeneralisasikan terhadap hasil penelitian. Dalam penelitian ini yang menjadi populasi adalah seluruh siswa kelas $\mathrm{V}$ dengan jumlah siswa sebanyak 23 siswa yang terbagi menjadi dua kelas, yaitu kelas V A dan kelas V B.

Sampel adalah "sebagian atau wakil populasi yang diteliti". Sedangkan Sugiyono berpendapat bahwa sampel adalah bagian dari jumlah dan karakteristik yang dimiliki oleh populasi tersebut. Dalam peneliti ini sampel yang digunakan adalah seluruh siswa kelas V A dan IV B dengan jumlah siswa sebanyak 23 siswa.

Sugiyono berpendapat bahwa "Teknik Sampling merupakan teknik pengambilan sampel. Teknik sampling yang digunakan dalam penelitian ini adalah nonprobality sampling dengan jenis sampling jenuh. Sampling jenuh adalah teknik penentuan sampel bila semua anggota populasi digunakan sebagai sampel. Sampling ini dilakukan apabila penelitian yang ingin membuat generalisasi dengan kesalahan yang sangat kecil. Dalam penelitian ini jumlah sampel yang digunakan adalah siswa kelas V (lima) SDN Sumbermulyo Kecamatan Bulu sebanyak 23 siswa.

Instrumen yang diterapkan dalam penelitian ini adalah soal tes sebanyak 25 butir soal berbentuk pilihan ganda. Analisis uji instrument meliputi analisis validitas, reliabilitas, tingkat kesukaran dan daya pembeda butir soal. Teknik analisa data pretest dan posttest digunakan untuk uji normalitas menggunakan chi kuadrat dan uji hipoteis menggunakan uji t test untuk mengetahui perbedaan pretest dan posttest. 


\section{Hasil dan Pembahasan}

Penelitian ini merupakan penelitian eksperimen dengan memberikan perlakuan model Think-pairShare terhadap kelas eksperimen dan tidak memberikan perlakuan Think-pair-Share terhadap kelas kontrol. Data penelitian ini terdiri dari data pretest dan data posttest pada hasil belajar IPA. Nilai hasil pretest sebagai pengukur kemampuan awal dan nilai hasil posttest diambil dari hasil pengerjaan soal oleh siswa, diambil dari hasil pengerjaan setelah dilaksanakannya pembelajaran menggunakan model Thinkpair-Share untuk kelas eksperimen. Sampel penelitian ini bersumber dari kelas yaitu kelas V A dan kelas V B. Kelas V A sebagai kelas kontrol sedangkan kelas V B sebagai kelas eksperimen. Untuk menentukan nilai kompetensi siswa dilakukan pretest dan posttest. Berdasarkan penelitian yang dilaksanakan diperoleh data hasil penelitian. Data yang diperoleh kemudian dianalisis untuk mendapatkan kesimpulan yang berlaku untuk seluruh populasi.

Analisis penelitian ini dibagi menjadi dua tahap yaitu (1) Analisis hasil awal dengan uji normalitas; dan (2) Uji homogenitas. Pada Uji normalitas nilai-nilai dalam penelitian digunakan uji Liliefors. Data yang digunakan adalah pretest kelas kontrol dan kelas eksperimen. Adapun hasil uji normalitas awal kelas Kontrol adalah sebagai berikut:

Tabel 1. Normalitas Awal Kelas Kontrol

\begin{tabular}{cc}
\hline Keterangan & Nilai \\
\hline Lhitung & 0,210 \\
$\mathrm{~L}_{\text {tabel }}$ & 0,242 \\
\hline
\end{tabular}

Sumber: Analisis Hasil Penelitian 2018

Dari data hasil pretest kelas kontrol diperoleh data yaitu: mean = 38 simpangan baku 19,4094 dan $\mathrm{L}_{0}=0,210$. Dengan banyaknya data $=12$, untuk $\alpha=5 \%$ maka dari daftar uji Liliefors diperoleh Ltabel $=$ 0,242. Karena $\mathrm{L}_{0}<$ Ltabel maka $\mathrm{H}_{0}$ diterima. Artinya nilai kritis data nilai awal siswa kelas kontrol pada tabel (Ltabel) lebih besar dari kritis hitung data nilai siswa kelas kontrol ( $\left.\mathrm{L}_{0}\right)$. Jadi dapat disimpulkan data nilai awal kelas kontrol tersebut berasal dari populasi yang berdistribusi normal. Kemudian pada perhitungan uji normalitas awal kelas eksperimen diperoleh hasil seperti pada tabel berikut:

Tabel 2. Normalitas Awal Kelas Eksperimen

\begin{tabular}{cc}
\hline Keterangan & Nilai \\
\hline Lhitung & 0,187 \\
Ltabel & 0,249 \\
\hline
\end{tabular}

Sumber: Analisis Hasil Penelitian 2018

Dari data pretest kelas eksperimen diperoleh data yaitu: mean 56,73 simpangan baku $=15,0671$ dan Lo $=0,187$. Dengan banyaknya data $=11$, untuk $\alpha=5 \%$ maka dari daftar uji Liliefors diperoleh Ltabel $=0.249$. Karena Lo < Ltabel maka $\mathrm{H}_{0}$ diterima. Artinya nilai kritis hitung data nilai awal siswa kelas eksperimen pada tabel (Ltabel) lebih besar dari nilai kritis hitung data nilai awal siswa kelas eksperimen (Lo). Jadi, dapat disimpulkan data nilai awal siswa kelas eksperimen tersebut berasal dari populasi yang berdistribusi normal. Selanjutnya untuk uji homogenitas diperoleh hasil seperti pada tabel berikut:

Tabel 3. Homogenitas Data Awal

\begin{tabular}{cc}
\hline Keterangan & Nilai \\
\hline$F_{\text {hitung }}$ & 1.6595 \\
$F_{\text {tabel }}$ & 2.94 \\
\hline
\end{tabular}

Dari perhitungan data akhir kelas eksperimen dan kontrol, didapat $S_{2}^{1}=376,7273$ dan $S_{2}^{2}=$ 227,018. Sehingga diperoleh $F_{\text {hitung }}=1,6595$. Sedangkan dari daftar distribusi $F_{\text {tabel }}$ untuk $\alpha=5 \%$ dengan $\mathrm{dk}_{1}=12-1=11, \mathrm{dk}_{2}=11-1=10$ maka $\mathrm{F}_{\text {tabel }}$ adalah 2.94. Karena $\mathrm{F}_{\text {hitung }}<\mathrm{F}_{\text {tabel, }}$ yaitu 1,6595 $<2,94$ maka $\mathrm{H}_{0}$ diterima yang berarti varians kedua kelompok sama atau data tersebut homogen. 
Pada analisis data akhir juga dianalisis dengan uji normalitas dan homogenitas. Uji normalitas nilainilai dalam penelitian digunakan uji Liliefors. Data yang digunakan adalah nilai posttest kelas kontrol dan kelas eksperimen. Dalam uji normalitas posttest kelas kontrol diperoleh hasil seperti pada tabel berikut:

Tabel 4. Normalitas Postest Kelas Kontrol

\begin{tabular}{ll}
\hline Keterangan & Nilai \\
\hline Lhitung & 0,204 \\
Ltabel & 0,242 \\
\hline
\end{tabular}

Sumber: Analisis Hasil Penelitian 2018

Dari data hasil posttest IPA kelas kontrol diperoleh data yaitu: mean $=70,33$, simpangan baku = 17,0098 dan Lo $=0.204$. Dengan banyaknya data $=12$, untuk $\alpha=5 \%$ maka dari daftar uji Liliefors diperoleh Ltabel $=0,242$. Karena Lo $<$ Ltabel maka $\mathrm{H}_{0}$ diterima. Artinya nilai krtitis data nilai kelas kontrol pada tabel (L) lebih besar dari nilai kritis hitung data kelas kontrol (Lo). Dengan demikian dapat disimpulkan bahwa data nilai posttest IPA siswa kelas kontrol berasal dari populasi yang berdistribusi normal. Selanjutnya pada uji normalitas posttest kelas eksperimen diperoleh hasil seperti pada tabel berikut:

Tabel 5. Normalitas Postest Kelas Eksperimen

\begin{tabular}{ll}
\hline Keterangan & Nilai \\
\hline Lhitung & 0,200 \\
Ltabel & 0,249 \\
\hline
\end{tabular}

Sumber: Analisis Hasil Penelitian 2018

Dari data hasil posttest IPA kelas eksperimen diperoleh data yaitu: mean $=77,82$ simpangan baku = 10,7872 dan Lhitung $=0,2$. Dengan banyaknya data $=11$, untuk $\alpha=5 \%$ maka dari daftar uji Liliefors diperoleh Ltabel $=0,249$. Karena Lhitung < Ltabel maka $\mathrm{H}_{0}$ diterima. Artinya nilai kritis data posttest siswa kelas eksperimen pada tabel (L) lebih besar dari nilai kritis hitung data nilai posttest kelas eksperimen. Dengan demikian dapat disimpulkan bahwa nilai data nilai posstest kelas eksperimen berasal dari populasi yang berdistribusi normal. Selanjutnya pada uji homogenitas data akhir diperoleh data seperti pada tabel berikut:

Tabel 6. Homogenitas Data Akhir

\begin{tabular}{cc}
\hline Keterangan & Nilai \\
\hline $\mathrm{F}_{\text {hitung }}$ & 2,49 \\
$\mathrm{~F}_{\text {tabel }}$ & 2,94 \\
\hline
\end{tabular}

Dari perhitungan data akhir kelas kontrol dan eksperimen, didapat $S_{2}^{1}=289,3333$ dan $S_{2}^{2}=$ 116,3636. Sehingga diperoleh $F_{\text {hitung }}=2$,49. Sedangkan dari daftar distribusi $F_{\text {tabel }}$ untuk $\alpha=5 \%$ dengan dk

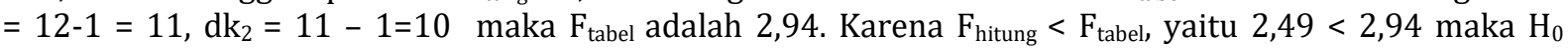
diterima yang berarti varians kedua kelompok sama atau data tersebut homogen.

Untuk menguji perbedaan hasil belajar dilakukan dengan menggunakan uji-t. Hal ini dilakukan untuk mengetahui perbedaan kemampuan akhir peserta didik sebelum dan sesudah diberi perlakuan. Hipotesis yang diujikan adalah sebagai berikut: $\mathrm{H}_{0}: \mu_{1}=\mu_{2}$ (hasil belajar IPA kelas IV yang diberi model Think-pair-Share sama dibanding siswa yang diberi model konvensional), $\mathrm{H}_{\mathrm{a}}: \mu_{1}>\mu_{2}$ (hasil belajar IPA kelas V yang diberi model Think-pair-Share lebih baik dari siswa yang diberi model konvensional)

Berdasarkan hasil perhitungan uji satu pihak antara hasil belajar kelas eksperimen dan hasil belajar kelas kontrol maka diperoleh nilai $\overline{X_{1}}=70.33, \overline{X_{2}}=76.73, S_{1}^{2}=289.3333, S_{2}^{2}=116.3636 . t_{\text {hitung }}=4,7312$. Hasil tersebut kemudian dikonsultasikan dengan $t_{\text {tabel }}$. Untuk $t_{\text {tabel }}$ dengan $d k=\left(n_{1}+n_{2}-2\right)=(12+11-2)$ $=21$ dan $\alpha=0,05$ dari tabel $t$ diperoleh $t_{\text {tabel }}=1,72$. Karena $t_{\text {hitung }}>t_{\text {tabel }}$ yaitu 4,7312 >1,72 maka $\mathrm{H}_{0}$ ditolak. Artinya nilai parameter hitung kelas eksperimen dengan kelas kontrol lebih besar nilai parameter pada tabel. Jadi, rata-rata hasil belajar dengan model Think-pair-Share siswa lebih aktif dibandingkan model pembelajaran konvensional yang cenderung monoton dan terpusat pada guru. 


\section{Simpulan dan Saran}

Berdasarkan rumusan masalah, pengajuan hipotesis, analisis data penelitian dan pembahasan, maka diperoleh kesimpulan bahwa metode Think-pair-Share lebih efektif terhadap hasil belajar IPA siswa kelas V SDN Sumbermulyo Kecamatan Bulu pada semester gasal tahun pelajaran 2017/2018. Hal ini terbukti pada analisis akhir dengan uji t satu pihak yaitu diperoleh thitung $=4,7312$. Dari daftar distribusi t dengan $\mathrm{dk}=12+11-2=21$ dan taraf nyata $5 \%$ diperoleh ttabel $=1,72$. Karena thitung $>$ ttabel maka H0 ditolak dan nilai rata-rata kelas eksperimen lebih besar daripada kelas kontrol sehingga hipotesis pada penelitian ini diterima. Penerapan model Think-pair-Share pada materi Organ Tubuh Manusi dan Hewan kelas V SDN Sumbermulyo, Siswa dapat mencapai ketuntasan belajar. Hal ini ditunjukkan dengan nilai tes akhir kelas eksperimen mencapai 90,91\% dari jumlah siswa yang mendapat nilai di atas KKM (70) dengan nilai rata-rata kelas sebesar 77,82. Sedangkan nilai tes akhir kelas kontrol mencapai $75 \%$ dari jumlah siswa yang mendapat nilai di atas KKM (70) dengan nilai rata-rata kelas sebesar 70,33.

Dengan hasil penelitian seperti yang disampaikan Peneliti dapat diketahui bahwa ada peningkatan yang cukup signifikan dalam penggunaan model pembelajaran Think-pair-Share pada materi mata pelajaran IPA maka guru dapat menggunakan model Think-pair-Share sebagai salah satu alternatif dalam mengajar.

\section{Daftar Rujukan}

Arikunto, S. 2012. Dasar-Dasar Evaluasi Pendidikan. Jakarta: Bumi Akasara.

Arikunto, S. 2013. Prosedur Penelitian: Suatu Pendekatan Praktik. Jakarta: Rineka Cipta.

Ayuwanti, Irma . 2016. Meningkatkan Aktivitas Dan Hasil Belajar Matematika Menggunakan Model Pembelajaran Kooperatif Tipe Group Investigation Di Smk Tuma'ninah Yasin Metro . Jurnal Sap Vol. 1 No. 2 Desember 2016 Issn: 2527-967x

Dimyati dan Mudjiono. 2006. Belajar dan Pembelajaran. Jakarta: Rineka Cipta.

Hamalik O. 2005. Proses Belajar Mengajar. Jakarta: PT Bumi Aksara.

Huda, M. 2014. Cooperative Learning: Metode, Teknik, Struktur dan Model Penerapan. Yogyakarta: Pustaka Pelajar.

Huda, Miftahul. 2014. Model-Model Pengajaran dan Pembelajaran. Malang: Pustaka Pelajar.

Lina Surayya, I Wayan Subagia, I Nyoman Tika. 2014. Pengaruh Model Pembelajaran Think Pair Share Terhadap Hasil Belajar Ipa Ditinjau Dari Keterampilan Berpikir Kritis Siswa. Jurnal Pendidikan dan Pembelajaran IPA Indonesia Undiksha. Vol 4, No 1 (2014)

Munirah. 2015. Sistem Pendidikan Di Indonesia: Antara Keinginan Dan Realita . Jurnal Auladuna, Vol. 2 No. 2 Desember 2015: 233-245

Nurkholis . 2013. Pendidikan Dalam Upaya Memajukan Teknologi . Jurnal Kependidikan, Vol. 1 No. 1 Nopember 2013

Prasetyo, Sutrisno, Mudzanatun. 2018. Pengaruh Model Pembelajaran Think Pair Share Berbantu Permainan Teka-Teki Berantai Terhadap Hasil Belajartematik Siswa Kelas V Sdn Gayamsari 01 Semarang. Jurnal Pesona Dasar Universitas Syiah Kuala. Vol. 6 No. 1, April 2018, hal. 1-13.

Setiawan, Hendri. 2014. Penerapan Model Pembelajaran Kooperatif tipe NHT (Numbered Head Together) untuk meningkatkan Aktifitas dan Hasil Belajar teknik dasar passing bola basket pada siswa kelas VII SMPN 1 Sukasada. Jurnal PJOK Undiksha. Vol 2, No1.

Slameto. 2003. Belajar dan Faktor-Faktor yang Mempengaruhinya. Jakarta: PT. Rineka Cipta.

Sugiyono. 2013. Statistika Untuk Penelitian Bandung: Alfabeta.

Sugiyono. 2015. Metode Penelitian Pendidikan. Bandung: Alfabeta. 
Sutrisno Perdana. 2016. Faktor-Faktor Yang Mempengaruhi Hasil Belajar Siswa Pada Pembelajaran Praktik Kelistrikan Otomotif SMK Di Kota Yogyakarta. Jurnal Pendidikan Vokasi UNY. Volume 6, No 1, Februari 2016 (111-120).

Raditya, I Wayan.2015. Pengaruh Model Pembelajaran Kooperatif Tipe Think Pair Share(TPS) Terhadap Hasil Belajar IPA Siswa Kelas IV SD Gugus Letda Made Putra Kecamatan Denpasar Utara Tahun Ajaran 2014/2015. Jurnal Mimbar Ilmu Undiksha. Vol 2 No 1.

Widarti, A. 2007. Efektifitas Penggunaan Model Pembelajaran Kooperatif Tipe Think Pair Share Terhadap Hasil Belajar Pokok Bahasan Segi Empat Pada Siswa Kelas VII Semester 2, Unnes. 